\title{
Ethnologies
}

\section{Microliteracy and the Discourse of Canadian Multiculturalism}

\section{Cameron Reid et Rachel Nash}

Volume 26, numéro 1, 2004

\section{Littératie}

Literacy

URI : https://id.erudit.org/iderudit/013340ar

DOI : https://doi.org/10.7202/013340ar

Aller au sommaire du numéro

\section{Éditeur(s)}

Association Canadienne d'Ethnologie et de Folklore

ISSN

1481-5974 (imprimé)

1708-0401 (numérique)

Découvrir la revue

Citer cet article

Reid, C. \& Nash, R. (2004). Microliteracy and the Discourse of Canadian Multiculturalism. Ethnologies, 26(1), 35-60. https://doi.org/10.7202/013340ar

\section{Résumé de l'article}

Cet article souligne la prolifération chaotique des " micro-littératies " multiculturelles au cours des décennies depuis que le gouvernement canadien a, le premier, porté le concept du multiculturalisme sur la scène nationale depuis le milieu des années 1960. Les auteurs définissent la littératie multiculturelle en termes d'orientations définies et soutenues vis-à-vis du discours multiculturel — orientations qui se manifestent par le biais de pratiques textuelles et sociales récurrentes. Durant les années précédent 1988 et la promulgation officielle du multiculturalisme au Canada, le discours s'est prêté à des ajouts naïfs et très optimistes au cours d'une phase de développement de la littératie que cet essai décrit comme une proto-littératie. Les efforts subséquents faits par le gouvernement canadien pour réduire ce discours au silence, alors même qu'il intégrait le multiculturalisme à sa politique officielle, ont frayé le chemin dans ce pays à une multiplication des littératies multiculturelles, une post-littératie qui a, durant ce processus, sévèrement fragmenté et miné le discours. 


\title{
Microliteracy and the Discourse of Canadian Multiculturalism
}

\author{
Cameron Reid and Rachel Nash \\ Department of English, University of Waterloo
}

Over the last two decades, new lines of critical inquiry have reshaped the landscape of literacy studies and have steered the question of literacy toward numerous fields that include (but are not limited to) ethnology, sociolinguistics, feminism, pedagogy, systems theory, discourse analysis, social semiotics, and post-structuralism. Research consolidated under such banners as The New Literacy Studies (NLS), ${ }^{1}$ Multiliteracies research, and The New London Group now ask "what counts as literacy?" (Gallego and Hollingsworth 2000: 8); how do literacies interact and collide with one another? (Gee 1996; Wilson 2000); how do literacies engender social identity? (Hull and Schultz 2002). Moreover, those swayed by the "social turn" (Gee 2000: 180) in literacy studies query the links between literacy and a diverse body of hot-button social issues that include ideology, power, gender, discourse, cultural context, and historical contingency. The critical turn in literacy research has also severed the ties between traditional approaches to the topic beholden to a capital L, autonomous model (Street 1984, 1995) Literacy, that is, literacy as the capacity to read and write, literacy as an acquired competence (e.g. Goody and Watt 1968; Goody 1977; Vytgotsky 1978) and approaches to the topic that presuppose a plurality of socially situated literacies (e.g. Gee 1996; Barton, Hamilton and Ivanic 2000; Gallego and Hollingsworth 2000; Hull and Schultz 2002).

1. As conceived primarily by Gee (1992, 1996, 2000), Street (1993, 1995), Barton (1994), Barton, Hamilton, and Ivanic (2000), and others. 
In light of current trends in literacy research, past critical agendas such as standardised testing and the socioeconomic impact of literacy/ illiteracy appear deferential to elite sociopolitical institutions and values. In certain quarters, therefore, the focus has turned to the tripartite relationship between literacy, discourse, and social practice, a relationship central to the issues under investigation in this paper. We define literacy as a patterned orientation to discourse among individuals and/or social collectives (i.e., families, groups, communities, cultures). Discourse users manifest their orientations to discourse, their particular uses and instantiations of discourse, through an assemblage of intersecting social and textual practices. As those practices become habituated and mutually reinforcing, as they coalesce and begin to set the terms (in the broadest sense of that word) by which discourse users avail themselves of the discourse, they graduate to become literacy practices. As iterative and sustained orientations to discourse, literacy practices enable individuals - both on their own and collectively - (a) to construct social roles and identities, (b) to negotiate relationships, and (c) to adapt to discourse communities.

Where social practices congeal and begin to take shape as established literacy practices, they come into conflict with other literacy practices, other ways of using, speaking, and valuing the same discursive resources. As this paper will illustrate, the struggle to regulate and contain literacy practices, to arrest them and make them cohere, advances ceaselessly. This struggle then underscores the volatility and the power dynamics at the core of literacy construction. Literacy research that posits a singular (or "autonomous") view of literacy largely ignores these more intensive aspects by defining literacy as a competence to be acquired, a finish line to cross. Yet from the social perspective, the neutrality, the very stability, of literacy falls into question, which predicts the eventual struggle among discourse users to establish and make cohere their own social and textual practices. With a proliferating body of discourse users generating an unlimited body of social and textual practices, resultant literacy practices maintain a permanent distance from their terminal point, their ultimate rendering. Thus conceived, literacies remain open to endless negotiation and contestation among discourse users attempting to establish a codified aggregate of literacy practices. Literacies change; they evolve and reconfigure themselves. The stakes are high in this contest given that the capacity to contain and to fix individual literacy practices coincides with the capacity to 
establish and maintain social identities, not to mention the power and privilege that such identities entail.

It will be shown by way of an extended analysis of multiculturalism in the Canadian context that multicultural literacy defies generalisability. It eschews fixed codes and stable skill sets, however ironic that may be given commonplace conceptions of literacy as little more than the dissemination of fixed codes and stable skill sets. Multicultural literacy not only possesses variable and indefinite borders, but fluid, internal dynamics as well. It morphs and reconstitutes itself, passing through periods of relative (though never total) stability and periods of profound flux and indeterminacy. Though multicultural literacy practices may crystallise, and thereby crystallise hierarchies and emergent subject positions, their internal structures cannot help but fragment given the competitive battles among discourse users to establish their own social and textual practices, their own uses and instantiations of multiculturalism discourse, as the seminal renderings of the discourse.

Yet multicultural literacy invariably bifurcates and subdivides along subterranean lines of flight, leaving a multiplicity of hermeneutic frameworks that serve wildly divergent social identities and competing versions of that which actually constitutes Canadian multiculturalism. Consequently, a growing quantity of multicultural microliteracies assume an uneasy alliance within the virtual whole of multicultural literacy in this country, leaving the discourse open to internal contradictions, even self-defeating practices. Moreover, wedges driven between various personal and collective constructions of multiculturalism leave discourse users at odds with one another, unwilling and ultimately unable to communicate with one another, to read and to interpret one another's codes, meanings, or values, as users struggle to advance their own literacy practices to the exclusion of others. So while multicultural literacy may best be defined in terms of an assemblage of competing literacy practices (i.e., microliteracies), the multiplicity of those practices, the enduring inexhaustibility and mobility of those practices, and the endless proliferation of meaning potentials associated with those practices, introduces a kind of illiteracy into the heart of multiculturalism, as users of the discourse must struggle to come to terms with the diverse and inconsistent strategies for reading, writing, and talking about multiculturalism in this country. 


\section{The Proliferation of Multicultural Literacies in Canada}

From the first whispers of Canadian multiculturalism in the late 1960s, to its official legal standing on the political stage of the late 1980s, around the time of the passage of the Multiculturalism Act, to its status over the last decade (or more) as a prolific body of localised multiculturalisms, a battle has persisted among users of the discourse to install the definitive rendering of multiculturalism in this country. Along the way, multicultural literacy has become an openly contested space, a catchall for an unruly band of discontinuous, rag-tag micro-literacies manifesting themselves by way of a diverse and often contradictory mix of linguistic, textual, and socioeconomic practices loosely tied together and again battling for prominence within the discourse as a whole. For those coming of age over the last several decades, uses of multiculturalism discourse have persisted and slowly mutated across the Canadian cultural landscape.

Consider the term culture. Raymond Williams warns that it "is one of the two or three most complicated words in the English language" (1985: 87). Culture, according to Williams, originally referred to "the tending of natural growth," and evolved by way of analogy. Eventually the definition extended itself to include the "process of human development" (87). Through various European languages, and from its roots in Latin to its appropriation by different intellectual movements, Williams noted that the term culture has continued to accrue new semantic depths. By extension, the compound term multiculturalism makes use of one of the major contemporary definitions of culture: "the independent noun, whether used generally or specifically, [...] indicates a particular way of life, whether of a people, a period, a group, or humanity in general" (90).

In multiculturalism, one can envision the daunting complexities of culture endlessly multiplied, as the term attempts to recognise both multiple ways of life (and all that that encompasses) and the relationship(s) between different ways of life. Not only does multiculturalism denote, for example, the way of life of ChineseCanadians - to the extent that those life experiences can be considered homogenous - but also the relationship of Chinese-Canadian children to (a) China, (b) the Chinese diaspora in general (including both recent and historical immigrants), (c) mainstream (i.e., Anglo-) Canadian culture, and (d) other ethnic groups within Canada. Leaving aside the 
complications of hybridity, this last point might be further subdivided given that Chinese-Canadians share a long and more developed history with certain ethnic groups (e.g. Koreans, Japanese) than with other ethnic groups (e.g. Greeks, Guatemalans). As Canadians who grew up with an evolving discourse of multiculturalism - that is, with ways of thinking and speaking about cultures and their relationships to one another - we recognise that the simplistic reduction of complex histories and social identities into static, ethnic labels indexes the enduring struggles faced by users of the multiculturalism discourse, given how the discourse itself uses Canadians. If taken seriously, the term multiculturalism denotes an almost overwhelming array of meanings that can be productively applied to a wide body of social practices and situations.

In his survey of the state of Canadian knowledge about multiculturalism, Enoch Padolsky described the immense scholarly energies currently focussed on this particular issue:

in only one recent year, 1996, five special journal issues were devoted to different aspects of multiculturalism (ethnicity, pluralism, etc.) and literature in Canada and Quebec [...]. At the same time, the breadth of ongoing study of Canadian multiculturalism within the various disciplines can be seen in the range of research review topics in the Berry and Laponce collection: demography, political philosophy in Canada and Quebec, immigration policy, human rights, ethnic history, ethnographic research, assimilation and ethnic retention, media, ethnic and multicultural attitudes, literature in Canada and Quebec, official and heritage languages, education and bibliographic studies. Nor is this research exhaustive. Work is being carried out in virtually every discipline around the Canadian phenomenon of multiculturalism (2000: 141).

As Padolsky's survey makes clear, numerous academic disciplines take multiculturalism as their object, each of which offers a distinct way of perceiving and investigating this multifaceted phenomenon. Moreover, the text types used in the various constructions of multiculturalism vary considerably; they are, in turn, popular, elite, entrenched, disposable, legally powerful, culturally powerful, accessible, and specialised, representing a wide array of diverse qualities and purposes.

However, despite their differences, these text types to some degree interact synergistically. While the larger and/or long-term impact of 
the different text types on one another may not be readily apparent in the here and now, researchers of multiculturalism discourse can observe more immediate signs of interaction between these various text types. For example, Linda Hutcheon and Marion Richmond's Other Solitudes (1990), a literary anthology produced just after the Multiculturalism Act came into law and during a time of enormous optimism in Canada about the possibilities of multiculturalism, included the text of the Multiculturalism Act itself, a central component of government multicultural discourse. Reviews of this and other multicultural anthologies appeared in newspapers and popular weekly newsmagazines, such as Maclean's. Multicultural anthologies have since been introduced into high school and university classrooms and have played a privileged role in forming the attitudes and experiences of the next generation of Canadian citizens, including government policy-makers and journalists. The government discourse of multiculturalism, for its part, has played an important role in bringing the term multiculturalism to popular consciousness and into popular use for the first time. In fact, Canada popularised the term multiculturalism in the world lexicon. The Oxford English Dictionary (1989) cites the first use of the now widespread term in the 1965 Canadian Government Report on Bilingualism $\mathcal{E}$ Biculturalism. In a sense, the entire discourse of multiculturalism coalesced around the government's engagement with the concept itself. Through these developments in what was becoming known as Canadian multiculturalism, press editorials began to critique the politics behind the Multiculturalism Act and ultimately the cultural phenomenon of multiculturalism itself. In these (and other) ways, government, press, and literary discourses of multiculturalism have converged and interacted. As a result, the often uncalculated effects of habitual ways of thinking and speaking about multiculturalism (i.e., multicultural literacy practices) have permeated Canadian sensibilities in multiple ways, and to an extent that previous generations would not have experienced.

The connection between Canada and multiculturalism has been intimate ever since the concept's formal introduction into Canadian discourse in the 1965 Report on the Commission for Biculturalism and Bilingualism. Shortly thereafter, in 1971, Trudeau's Liberal government presented multiculturalism as state policy, in part as a political manoeuvre to offset the impact of the introduction of official bilingualism and to placate the "ethnics" who increasingly objected to 
a simplistic bicultural vision of the nation. Throughout the 1970s and 1980s, the Canadian government treated multiculturalism with varying degrees of interest and enthusiasm, while frequently shuffling the policy between several departments and ministerial portfolios. However, in 1988, the Mulroney government dramatically increased the formal status of multiculturalism through the passage of the Multiculturalism Act.

However, multicultural literacies, which again we define in terms of patterned orientations to multicultural discourse made manifest by sanctioned social and textual practices, are not solely negotiated by way of government policy initiatives. Indeed, numerous cultural and social sources have sought to lay claim to unique brands of multicultural literacy in Canada, and often in multiple genres. For example, immigrant groups, educators, religious organisations, and business associations have both constructed and used multiculturalism through the production of any number of reports, fact sheets, community newsletters, children's stories, and so on. In addition, alternative renderings and uses of multiculturalism - a concept that may occasionally be referred to by other names - lurk in numerous and somewhat unorthodox venues as diverse as student newspapers, online chat groups, and bathroom walls.

Since 1988 and the passage of the Multiculturalism Act, multicultural literacy practices have continued to evolve and reshape themselves as the discourse itself has shifted away from a focus on fairly established European cultural groups to newer immigrant communities that more profoundly differ from the Canadian norm, for example, Asian, African, and Central American communities. Accordingly, the general focus of early multiculturalism policy, which included the preservation of heritage languages and the promotion of cultural insignia such as food and festival, has also evolved, especially in terms of multiculturalism discourse's current acknowledgement of issues such as racism and cultural awareness. As well, since its first appearance in Canada in the 1960s, multiculturalism has thrived globally, becoming official policy in other nations, most notably Australia, while informing policy matters in nations such as Britain and the United States.

As a prime example of multicultural practices in this country, Canada celebrates "Asian Heritage Month" every May. In venues across the country, Asian heritage manifests itself through music, food, literature, cultural and social events; as well, panel discussions and public forums are held on the more problematic aspects of the Asian experience 
in Canada, for example, racism, discrimination, and assimilation. Many types of text participate in this event, including, novels such as Rohinton Mistry's Indo-Canadian novel, A Fine Balance, recipes for Vietnamese sandwiches, websites providing an overview of the month's events, pamphlets publicising kabuki theatre, glossy magazine articles about the newest Punjabi fusion bands, newspaper interviews with recent Hong Kong immigrants, circulars about the wonders of Chinese medicine, and so on. The number and diversity of texts surrounding just this one multicultural event indicate the vast textual resources that might be tapped for a study of multicultural microliteracies in Canada.

\section{From Protoliteracy to Post-Act Multiculturalism: A Silencing of the Discourse}

Glimpses of a radical form of multiculturalism discourse appear in the Canadian government's problematic early publications on the topic of multiculturalism. Over what we define as a protoliterate period in the evolution of Canadian multicultural literacy, pre-Act conversation during the 1970s and 1980s resulted in relatively simplistic, though uncoded and freely formed, uses of multiculturalism, as compared to the literacy practices introduced in the years just following the Multiculturalism Act (which will be discussed below). Prior to 1988, there had been a willingness among makers of the discourse to experiment with the topic of multiculturalism, to redraw the borders of Canada, and to posit a liberal-democratic hope in accordance with newly defined sensitivities to multicultural matters. Multiculturalism was originally constructed as a ground-breaking, iconoclastic, liberal, and progressive policy, a new way of talking about things; it was both vital and experimental, exploratory and unfettered by strict codings, and yet there remained a critical innocence among public/political uses of multiculturalism.

The proceedings of a 1976 Canadian government conference on multiculturalism expressed an early optimism about multiculturalism in Canada - an optimism that extended even to those participants who, like Douglas Fisher, proclaimed themselves to be "cynical" (Canadian Consultative Council on Multiculturalism 1976: 15). The proceedings of the conference opened with a panel of six public figures sharing their individual perspectives on the issue of multiculturalism. Monique Bégin spoke of her family background: "I was born in Rome 
to a Flemish mother and a French-Canadian father who [...] lived several years in different parts of the world. My parents each spoke eight languages" (3). Charles Lynch reached even further back into his family history, explaining the origins of his surname in Austria and, later, Ireland; Lynch noted that the hanging of an ancestor led to the creation of the verb "to lynch" (21).

Other contributors to the conference, such as Arnold Edinborough, narrated their personal perspectives on multiculturalism through the broader sweep of Canada's past. Edinborough himself translated historical events into his own rudimentary terms: "The Irish came because there weren't any potatoes, and the Scots came because there [sic] were sheep in their own country" (11). On the second day of the conference, the then Minister Responsible for Multiculturalism, John Munro, reminded his audience about Canada's historical pluralism and drew on the experiences of one particular group - Ukrainians - in one particular region of Canada - the prairies - to illustrate how ethnic groups within Canada evolved through their interaction with their new environments (121). In all, what we have during this early stage of multiculturalism in Canada is a literacy up for grabs, both malleable and open to definition. These early discussions, though, draw our attention to the complex relationships between power - the power to make multicultural literacy - and the early construction of multicultural literacies. Power, vis-à-vis literacy, is not only measured in terms of one's capacity to decode or interpret discourse but to meaningfully contribute to it, to change that discourse, and for it then to evolve. One might ask at what level codes are negotiable? For example, individuals cannot change the alphabet, though they can use the alphabet to render endlessly different variations. ${ }^{2}$

Despite the diversity of sources contributing to the early renderings of Canadian multiculturalism, a strong shared pattern of conservatism began to animate the discourse around the time of the Multiculturalism Act and in the years since. By conservatism, we mean the impulse to protect and reproduce existing values, beliefs, and social structures, those that generate the need to resist change and maintain the status quo. In fact, the discovery of a pronounced conservative predilection at the heart of multicultural discourse seems surprising, especially given

2. On this point, Halliday's $(1978,1985)$ discussion of closed and opened registers comes to mind. 
(a) the currency of the discourse - consider that multiculturalism marks an innovation, a departure from older ways of thinking about issues such as race relations and Canadian identity - and (b) multiculturalism's more frequent and explicit association with liberalism and progressivism, rather than conservatism.

Cut to February 2000. Official Canadian Multiculturalism has progressed considerably, as have the literacy practices surrounding this multipronged phenomena. The passage of the Multiculturalism Act in 1988 guaranteed legal status for multiculturalism and, therefore, the Annual Report (2000) on multiculturalism produced by the federal government sought to detail new and ongoing multicultural initiatives from every sector of the government. In his single-page foreword to the report, Prime Minister Jean Chrétien praised multiculturalism. He reminded his readers that Canada "is a diverse and cohesive society, where no single culture dominates. This may not be the easiest path to national unity but it has the great advantage of encouraging each and every member of our society to participate and contribute, while maintaining his or her cultural identity" (Annual Report 2000: iii). Hedy Fry, the Minister Responsible for Multiculturalism, echoed the sentiments of Chrétien in her own introduction to the report: "Canadians value ethnocultural diversity most for the contribution that it makes to our quality of life" (v). Neither politician, though, recounted a personal experience of multiculturalism, nor did they offer concrete examples of multiculturalism in practice. Rather, Chrétien and Fry spoke in generalities and abstractions, without grounding their assertions about multiculturalism in specific detail. In general, their prose would seem to have dropped the folksy and personalised dialogue of their predecessors on this issue.

We argue that the institutionalisation of multiculturalism played a key role in the government's adoption of more restrictive or conservative practices vis-à-vis multiculturalism. The passage of the Multiculturalism Act in 1988 elevated Canadian Multiculturalism from policy to law, and again it marked the transition between two distinct periods of multicultural literacy in Canada. The Act set in motion changes to the government's habitual ways of constructing and using multiculturalism, their ways of orienting themselves to the discourse, although not always in predictable ways. We might, for example, have expected to find more precise and complete definitions of multiculturalism and its related concepts (e.g. race, ethnicity) in a newly legalised discourse of 
multiculturalism; in fact, we might have expected that the law would have woven a kind of linguistic precision into the rendering of the discourse, so as to avoid possible equivocation. However, in the case of contemporary multiculturalism, legalisation did not fix even the most key terms of its discourse. Government texts did not substantively define multiculturalism, save their generalised and unrevealing depictions of multiculturalism as somehow integral to the life and values of this country. After 1988, the closest attempt to explicate this key term occurred in a government pamphlet on the subject with the rhetorically coy heading Multiculturalism... Canadians together, and its ensuing statement that "multiculturalism is simply life in this country, it is Canadians living and working together." These platitudes effectively avoid the difficulties of a substantive definition. Compare these (non) definitions with the far more substantial, yet highly accessible, definition of multiculturalism found in a pre-Act glossary of key terms in the report entitled, Multiculturalism: Building the Canadian Mosaic (1987). This report defined the concept as the "[r]ecognition of the diverse cultures of a plural society based on three principles: we all have an ethnic origin (equality); all our cultures deserve respect (dignity); and cultural pluralism needs official support (community)" (87).

The post-Act texts' apparent reticence to define multiculturalism and other key terms typified a legal desire to suspend potential challenges to that definition; an undefined term also lessened potential disagreements about how a given term represented or misrepresented certain social or political relationships. By avoiding a definition of multiculturalism, especially one entrenched in law, the Multiculturalism Act allowed itself to avoid potentially debilitating public or political controversy over the rendering of the term itself. Where legislative projects in other contexts endeavoured to include precise definitions of controversial or contentious terms, they did so at their own peril. For example, after heated and extensive debate over the content of the proposed Canada Clause - a clause that had attempted to delineate the identity and values of the Canadian people - the Charlottetown Accord (as a whole) failed, along with its problematic clause. Given that those who penned the Multiculturalism Act were able to turn their legislative mandate into law without defining multiculturalism, the term itself had been able to retain its suggestive quality, its social and political promise. Interpreters of multiculturalism in Canada, both now and in the future, will be able to supply specific content to the concept 
according to their own intellectual, social, or political predilections. This capacity among users of the discourse has already hastened the fragmentation of multicultural literacy in this country by perpetuating a plurality of microliteracies over the last decade or more. Because the government held back on seriously defining the concept of multiculturalism, the concept has since been able to satisfy multiple interests while remaining strong evidence of the Canadian government's ongoing commitment to the problems of racial and ethnic inequality.

Although contemporary multiculturalism discourse, by shutting down the semantic resonances, the very heteroglossia, of its given texts, appears compromised by the strictures of legal language, when compared with its earlier counterpart, the later discourse does serve important political functions. First, this attitudinal shift relieved the Canadian government of the excrescences of earlier, less polished renditions of multiculturalism. For example, a 1984 public information booklet, Multiculturalism: Celebrating Our Differences, depicted grinning Aboriginal nuclear families in cartoon form, with a caption that read: "Their rough but simple life was in harmony with nature and the environment" (unnumbered page). Second, the highly controlled articulation of second-generation multiculturalism permitted the government to remain sensitive to racial and ethnic issues, but without threatening the status quo in any way. We argue that much of contemporary multiculturalism's political utility lies in its apparent progressivism and idealism; as such, multiculturalism has provided the government with an official alibi in charged debates about ethnic and race relations.

Légaré (1995) noted that multiculturalism "permits space for difference - in carefully structured ways" (352). The government discourse's lexis avoids terms which might evoke the past, even very basic terms such as history, the past, or immigrant, but when needed, the discourse has managed this cluster of concepts through a specialised set of terms which include heritage, origin, or first-generation Canadian. The word heritage plays a significant role in how government texts have profoundly influenced multicultural literacies in this country. Indeed, the catchall Department of Canadian Heritage currently houses the government's multiculturalism program. At first glance, the word heritage may seem synonymous with words like the past, history, immigration. The word heritage, though, has become the workhorse of Canadian multiculturalism precisely because it bears some of the representational 
weight of the past while its connotations mitigate against more problematic aspects of the past. The term heritage manages to celebrate the past in a strategically vague manner: heritage brings a dignified ring to non-specific notions of family, traditional food and costume; by implication, this term directs attention to non-controversial aspects of given cultures as their substantive content. Because the term heritage carries a positive and more specifically cultural connotation than other lexemes excluded from the discourse, it represents a safer, less overtly political choice. In other words, while the past, broadly conceived, must necessarily be addressed at certain moments within the texts, heritage rendered the past slightly out of focus, sepia-toned, and safely out of the realm of controversy.

Similarly, throughout the Multiculturalism Act, the word origin, as in the exemplary phrase "individuals and communities of all origins," provided another way of lexically constructing the past as clear of all controversy. Origin rendered earlier processes (i.e., verbs) in terms of place rather than time: the spatial and temporal relationship between source and end product collapses into a primarily spatial relationship through the use of the term origin. Common phrases which use the term in the Act (e.g., "point of origin," "place of origin," but never the phrase, time of origin) clarify this relationship. Adrienne Rich (1986) observed a similar effect: "I've been thinking a lot about the obsession with origins. It seems a way of stopping time in its tracks" (227). One's origin, like one's heritage, remains generic, unspecified, and vague. Furthermore, the time and distance implied between origin and the persistent now of the Act remains undeveloped and unavailable to official users of the discourse. This gap which includes history and immigration, colonisation and struggle — the stuff of Canada's past — remains significantly unarticulated and stripped of its potential voice within multiculturalism.

This absence of the past complements the overall rhetorical strategy of the multiculturalism discourse. In short, the past does not exist because the past provides an enormous source of potential grievance (and therefore potential controversy) for those whose presence the Act foregrounds, those of non-English and non-French ancestry. Consider the fact that in terms of time, the past remains the primary site of all injustice, all wrongdoing. Travelling along these same lines of thought, Northrop Frye (1982) made the claim that "the past in Canada [...] like the past of a psychiatric patient, is something of a problem to be resolved" (48). We suggest that this "patient," at least in terms of 
multicultural literacy practices, remains in denial. In effect, multicultural literacy within the government has successfully constructed multiculturalism as an inappropriate forum for the discussion of a litany of troublesome historical episodes, including, as Padolsky notes,

immigration policies based on an ethnic/racial pecking order; assimilationist and Anglo-conformist institutional practices (including language suppression); the Komagata Maru incident; the Chinese Head Tax and Exclusion Act; the lack of voting rights for some groups; the Japanese-Canadian wartime internment; the rejection of Jewish refugees from Nazi Europe (2000: 139).

In addition to the unarticulated past, the present remains unevaluated and the future, through a rhetoric of posterity, functions as little more than a site of potential or promise. ${ }^{3}$ By subtly rendering the past and present off-topic, while foregrounding a naively hopeful image of the future, government multiculturalism has forestalled questions about Canada's moral credibility and responsibility with regard to historical injustices and their ongoing effects.

The discursive caution in governmental multiculturalism has its roots in a larger political context: in the last few decades several minority groups - groups foregrounded by multiculturalism - have brought forward grievances about past injustices perpetuated by the Canadian government. Japanese-Canadians, for example, seeking redress for their internment during World War II, have been particularly successful in achieving recompense for, and official recognition of, their mistreatment. Such organised claims represent a general climate of intolerance for past wrongs. For governments who perceive themselves to be deficient in both monetary and symbolic capital, the desire to avoid public forums on contentious issues necessitates the tightly controlled language of official documentation. In general, the modern uses of multiculturalism carefully limit their focus on the past in order to reduce the current risk of accountability within the Canadian government.

Comparatively, multicultural protoliteracies dramatically foregrounded history, as in the following passage from a booklet on multiculturalism in the pre-Act period:

3. As an example of the hopeful actions this discourse proposes for the future, consider one example from the Act: "The Minister shall [...] encourage and assist individuals, organizations, and institutions to project the multicultural reality of Canada in their activities in Canada and abroad." 
we began with the prehistoric arrival of the antecedents of our Native peoples, proceeded to the period of European discovery and exploration, the subsequent colonisation and settlement by the French and English, the railway, the inevitable political union, modern immigration and ended with the cultural mosaic of present-day Canada (Multiculturalism Program 1984).

Notice that this passage not only speaks in historical terms and refers to immigration, but that its processes make use of the before-now tense and the completed aspect. This grammatical evidence alone sets this passage (and this text) in direct contrast with its more recent, postAct counterparts. Furthermore, this passage's time circumstances refer to prior happenings. For example, "began," the first process noted above, clearly happens in the past, and is completed. These differences amount to a profound shift between the two periods of multiculturalism in terms of representation of the past, a shift symptomatic of an attitudinal shift in the contemporary discourse.

The erasure of political and geographical place (e.g., nations, regions, and states) from post-Act multicultural literacies made the possibility of differentiated ethnicity more difficult because it excluded the most important category used to distinguish between ethnic groups: place. The resulting essentialised ethnicity simplified multiculturalism by minimising its complexity and its contradictions. This simplification, in turn, made multiculturalism easier to promote and less politically volatile, partly because it utilised existing prejudices; it advanced ideas and judgements about ethnic difference founded on the pervasive binary of ethnic and normal Canadians. In short, the exclusion of place from newer multiculturalism discourse preserved essentialised ethnicity, that which favours the status quo because it reproduces the centrality of the Anglo- or Franco-Canadian norm, while simplifying and marginalising the complexity of all others. Emptying multiculturalism of political place, with the exception of Canada, reinforced essentialised ethnicity which then covertly, and inoffensively, reinforced mainstream privilege and prejudice.

In all, we hold that the consequences of governmental evasions and silences vis-à-vis multiculturalism have had a profound impact on the splintering of multicultural literacies, since the passage of the Act. Instead of avoiding sociocultural tensions in this country, muddled governmental renderings and uses of multiculturalism would seem to have heightened racial and ethnic divisions in this country. Padolsky 
(2000), using changes in the larger politico-social sphere to guide his estimations, argued that future directions in discursive constructions of multiculturalism would foreground race more prominently, especially given the increasing number of non-traditional (i.e., non-European) immigrants to Canada. Padolsky further ventured that an enhanced emphasis on race would challenge the two — or three - founding nations hypothesis ${ }^{4}$ on which much of multiculturalism theory still implicitly depends. Furthermore, cultural survival would become an increasingly relevant concern in light of a strong demographic trend toward assimilation and/or mixed-race, mixed-ethnicity Canadians. Finally, Padolsky forecasted that the contentious question of "the place of Aboriginal peoples within the multicultural discourse" (154) would attract considerable attention and debate within the discourse. In all these ways, mute multicultural literacies may only have distracted users from pursuing contentious political and social debate. In the long term, the time for serious debate may yet present itself, possibly in the wake of violence stemming from ineffectual multicultural policies within the Canadian context.

\section{Going Public: Beyond the Promise of Multiculturalism}

An issue that has received a good deal of media scrutiny in recent years concerns the celebration of largely Christian holidays (by way of any number of communal or creative practices) in a progressively multicultural school system. News reports typically single out multicultural policies and the zealous administrators who enforce such policies as the sinister forces at work in these situations. In the eyes of a resentful community, multiculturalism has overextended its reach by prohibiting or severely curtailing Western cultural traditions associated with such holidays as Christmas. In line with current news values that elevate the importance of situational agonism, the Canadian public receives its conventional image of, and perspective on, multiculturalism through narratives of cultural contestation. At worst, Christmas-is-banned stories in the news media appear to betray the ideal, if not the spirit, of multiculturalism, as evidenced by the Multiculturalism Act's promise of inclusiveness, inter-ethnic harmony, and the equal representation of cultural symbolism.

4. The number of founding nations depends on whether one counts Native peoples, along with France and England. 
Media representations of multiculturalism, though, are not uniformly negative. The appearance of a new form of multiculturalism as a global marketing device may have been inevitable given the ever-increasing role of multiculturalism discourse in Canada (and elsewhere), and given advertising's parasitic nature and sensitivity to developments in popular consciousness. In her anti-corporate primer No Logo (2000), Naomi Klein examined popular sales strategies aligned with multiculturalism, those that she described as "market masala" (117). For example, the Bennetton ad campaigns of the early 1990s, featuring "[t]he upbeat smiling faces of mixed race models" (Hoechsmann 1997: 185), provide a contentious example of how Bennetton has aggressively used multiracial and multiethnic models as themes to sell its products. Although the marketing strategies of Bennetton and its imitators may appear to be a positive development, one that addresses concerns about the need for more diverse and well-rounded racial representations in the media, Klein argued that the use of explicit diversity in advertising has actually supported a new kind of global homogenisation. Klein made the argument that "[t]his candy-coated multiculturalism has stepped in as a kinder, gentler packaging for the homogenising effect of what Indian physicist Vandana Shiva calls 'the monoculture' - it is, in effect, monomulticulturalism" (117).

While not as clearly offensive as the prevalent North American monocultural strip malls and fast food joints, mono-multiculturalism may just as effectively replace unique cultures and their equally unique social practices. Instead of replacing local culture with monoculture, mono-multiculturalism has replaced multiculturalism itself with carefully selected representations of different racial exemplars usually engaged in harmonious and implicitly egalitarian interactions. As an example of mono-multiculturalism, consider an ad that features beautiful young models ranging from extremely fair-skinned through to very darkskinned. In the ad, the models hold hands while wearing examples of each other's traditional clothing. A red-haired, freckled young woman sports a sari; a black man with an afro wears a sweater with a traditional Scandinavian design, and so on. Yet this group of idealised individuals who reflect the public face of multiculturalism exists exclusively in the world of advertising; in effect, advertisers do not represent real individuals struggling to come to terms with cultural differences rooted in unsightly prejudices and inequalities of power. In addition to providing a startlingly graphic jolt to conventional sensibilities (creating a buzz in 
the marketplace), mono-multicultural images easily translate across multiple cultures, providing advertisers and their clients with efficiencies of scale.

In short, if the mono-multiculturalism suggested by advertising begins to take a serious role within perceptions and uses of multiculturalism, the particular handling of multicultural images within advertising will severely limit the scope of multiculturalism discourse. The effects of mono-multiculturalism have the potential to erode the unique qualities of different national discourses of multiculturalism, while further robbing multiculturalism itself of its potential role as a meaningful and important site for the consideration of difficult and challenging issues. We have only to examine instances of tribal-based warfare in the last decade - for example, the genocidal efforts in former Yugoslavia and in central Africa - to grasp the ongoing need for serious dialogue about social, cultural, political, and historical relationships between different ethnic and racial groups. Multiculturalism discourse has the potential to provide a forum for such discussions, though not when overtly trivialised by way of insincere and cynical marketing campaigns.

Recent developments in Canadian public affairs do not reflect the increasing popularity of the discourse of multiculturalism, whether as marketing strategy, diversity management tool, or descriptor of fusion events such as the mooshu calzone. Abu-laban and Stasiulus (1992) catalogued the mounting critiques against multiculturalism policy in Canada, those that continue unabated into the present day. The first and most wide-ranging group of critiques come from academics who, not surprisingly, find numerous, sometimes contradictory reasons to distrust and denounce multiculturalism. Prominent academic antimulticulturalism arguments include (a) that multiculturalism covertly promotes assimilation, (b) that it fuels anti-Quebec sentiment, (c) that it offers a placebo for minority groups, and (d) that multiculturalism leads to cultural relativism, as Reginald Bibby and, later, Neil Bissoondath, similarly concluded. In a popular indictment of multiculturalism, Canadian writer and Caribbean immigrant Neil Bissoondath (1994) constructed multiculturalism as a deeply flawed and ultimately divisive system that should be replaced with an emphasis on a unified Canadian identity. Padolsky documented the tremendous reception of Bissoondath's work, noting that he 
received extraordinary publicity [...]. Excerpts were pre-published in The Globe and Mail, and the book was given immediate coverage on CBC's influential radio programme Morningside. Bissoondath's ideas were widely reviewed in Canadian newspapers and elicited numerous editorials (and letters to the editor) querying or defending multiculturalism. The degree of interest can be illustrated by Bissoondath's one-day promotional visit to Ottawa, on 4 October 1994, which included 13 interviews (in that single day) and a reading at the prestigious National Library of Canada (2000: 140).

Bissoondath almost single-handedly introduced a new way of thinking multiculturalism in this country, a new strain of multicultural literacy. He argued that as the ultimate spectre of cultural relativism, multiculturalism holds the possibility of such extreme practices as female genital mutilation, the use of parallel system Islamic judicial law within Canada, and separate schools based on racial identity. Such concerns in combination with problematic media representations have helped to engender an alarming perception of multiculturalism among members of the Canadian public who view the phenomena as not only a threat to national unity and Canadian values, but a powerful tool for xenophobic ethnic communities who wish to sap Canadian resources in the service of reinforcing their cultural separation.

The contribution to the discourse of multiculturalism that Bissoondath has opened the door to, and become a kind of rallying cry for, all manner of conservative and reactionary treatments of multiculturalism in this country, especially on the political stage. For example, the general consensus among political parties who brought multiculturalism policy into existence has been disrupted by two parties in particular: the Bloc Québécois and the Reform party - the latter of which eventually re-formed as the Alliance party. ${ }^{5}$ We concentrate our attention on the Alliance party which as of early 2004 continues to occupy the influential role of official opposition and opposes multiculturalism as national policy. Patten drew attention to the important role of multiculturalism in establishing the Alliance party's identity in its early days, noting that "Reform's policies on immigration and multiculturalism have been among the most discussed of the party's

5. In recent months the political landscape in Canada has again shifted with the merging of the Progressive Conservative party and the Alliance party. In the coming analysis we refer exclusively to Alliance party policy, as Conservative party policy on most matters, including multiculturalism, has yet to be finalised. 
New Right populist policies" (1999: 35). Patten described the development of the Reform party from its folksy grassroots beginnings to its much more polished presence by the late 1990s. Like the discourse of the government itself, Reform (and now Alliance) constructions of multiculturalism have been toned down, becoming more controlled and less extreme of late: "While Reform may have removed the more obviously xenophobic language from its culture and immigration policy platforms, the party's social conservatives are to a considerable extent content with the more cautious liberal market policy terminology that has taken its place" (39). In other words, the Alliance party has offered the following official policy statement on multiculturalism:

\begin{abstract}
We affirm Canada as a society where people of different races and cultural backgrounds live and work together as Canadians, and we welcome the resulting cultural enrichment and enhanced economic prosperity. We will therefore uphold the freedom of individuals and families to nurture aspects of culture that are important to them. While cherishing our diversity, we believe that multiculturalism is a personal choice and should not be publicly funded (Multiculturalism 2002).
\end{abstract}

In this more broadly acceptable version of old Reform party rhetoric, we see indications of what may be a significant development in the party's particular rendering of multiculturalism, that is, the new importance of money. This statement suggests that because a multicultural society opens the door to "enhanced economic prosperity," the Alliance will "uphold the freedom of individuals and families to nurture" their own cultural values and propensities. This brief text expresses the Alliance party's conservative fiscal policies and social policies. Abu-ladan and Stasiulus (1992) accurately described the Reform party in the early 1990s as "populist in orientation, endorsing the free-enterprise system, a limited role for the state, particularly in social policies, and fiscal restraint" (372). The Alliance perceived that government-sponsored multiculturalism, like so many other aspects of the Canadian social system developed during the 1960s and 1970s, represents a dubious luxury that the nation can no longer afford to sustain. However, in keeping with the party's emphasis on individual rights, the Alliance do concede that if Canadian citizens wish to be multicultural, however that may be construed, presumably in the privacy and sanctity of their own homes, the Alliance will not stand in their way. As they say, "multiculturalism is a personal choice." 
While the Alliance policy statement dismisses public support for multiculturalism programming, the party does not abandon multiculturalism discourse tout court. An abstract discursive representation of multiculturalism, which we see evidence of in the congratulatory and concessionary subordinate clause, "while cherishing our diversity," comes at a price even the Alliance party can afford. This high-minded rhetoric reinforces the long-standing multicultural literacy practice of paying lip service to the ideal and the promise of multiculturalism, and thereby currying the attendant political points for advocating personal and/or collective freedom in this country, while simultaneously upholding a policy that denies public monies to a potentially expensive, resource-sucking apparatus such as an actual department of multiculturalism. Given recurring accusations of racism that dog the Alliance/Reform, a savvy and literate nod to multiculturalism through the patronising commitment to "uphold the freedom" of multicultural types offers a way for the party to soften its public image and portray itself as a moderate or centrist voice in Canadian politics.

Although appearing largely unrelated on the surface, the uses and abuses of multiculturalism by the Alliance party and the advertising community reflect a consistent trend in the discourse: for both groups, economic concerns take top priority. In marketing multiculturalism discourse, the quest for profit provides the inevitable backdrop to the use of multiculturalism and thus motivates the entire operation. So while not immediately foregrounded, given that marketing campaigns do not usually foreground their own pecuniary ambitions, economic concerns clearly underscore marketing strategies in this area and simultaneously undermine any serious issues that multiculturalism raises. If advertising's patterned orientation to multiculturalism discourse eventually proves ineffective as a marketing tool, this strategy will quickly be dismissed, recognising that marketing has no special allegiance to multiculturalism (or anything else for that matter) except as an economic driver. Given how both the Alliance party and advertising use multiculturalism, they further deprive the discourse of a useful staging ground for the discussion of complex social, cultural, political, and historical issues. The constructions of multiculturalism offered by both marketing and the Alliance party offer little substance for dealing with matters that desperately need consequential dialogue and new and effective modes of social debate. 
We characterise post-Act multiculturalism discourse as a post-literate phase in the evolution of multicultural literacy in this country. In preAct, protoliterate multiculturalism discourse, multiculturalism had yet to take formal shape and so became a literacy up for grabs, a yet-to-be finalised compendium of meaning potentials that often served a liberaldemocratic hope. In the wake of governmental efforts to mute the discourse of multiculturalism and delimit its capacity to engender new and productive meanings, users from all corners of the Canadian cultural landscape have availed themselves of the opportunity to take up the underdeveloped concept of multiculturalism in the service of their own political, social, and/or economic agendas. Multiculturalism, at one and the same time, points to outward cultural insignia (food, dress, etc.), "enhanced economic prosperity," a sapping of Canadian financial resources, social inclusion or, at its extreme, assimilation, social exclusion or isolation, xenophobia, extreme cultural practices, a defiance of Canadian values, a disruption of Canadian unity, cultural relativism, profitable (though time-limited and ultimately disposable) marketing strategy, personal choice, public controversy, liberal-democratic hope, freedom, unnecessary constraint, a panacea for racial and cultural ills in this country, a predictor of racial and cultural ills in this country, a charged public forum for voicing historical or intercultural grievances, an innocuous and abstract rhetoric, and so on. The list is potentially infinite and moving in numerous directions. Multiculturalism is any of these things, all these things, and none of these things, all at the same time. Multicultural microliteracies in the country will surface and submerge at regular intervals, colliding with and contradicting one another, while all battling for prominence on the public stage as the definitive rendering of multiculturalism.

If marketing and Alliance discourse prove to be accurate indicators, future multicultural literacies in Canada may become text heavy, primarily composed of showy and outward textual traces that involve only a limited spectrum of social activity. In such a scenario, a proliferation of relatively empty signs (i.e., textual lip service) takes the place of authentic and substantive dialogue on multiculturalism, that which might support concrete improvements to the lives of Canadians. In addition, this reductive form of multiculturalism would not prompt calls for either its revival or its replacement, in the way that the eradication of the discourse as a whole would. Instead, reduced and more innocuous multicultural literacy practices would take the lead in 
orienting discourse users to multiculturalism while failing to provide a meaningful set of resources for making new and challenging contributions to multicultural literacies in Canada. Consequently, ineffectual literacies could become an asset for those who wish to block serious discussion of, say, immigration policies, racism, and historical injustices, and a liability for those who wish to engage such matters.

Finally, the move to globalise multiculturalism could further the chaos and the proliferating subdivisions of multicultural literacy in the Canadian context. Market forces have begun to determine that multiculturalism appeals to (read: is sellable to) a global audience an audience that easily subsumes the more limited audience for Canadian multiculturalism alone. Consequently, a multiculturalism unwilling to go global, as it were, may come to be viewed as provincial or protectionist on the world stage, thereby pressuring Canada to adopt global aims and abandon its once unique, homegrown discourse of multiculturalism.

\section{Conclusion}

The current aggregation of multicultural literacy practices in the post-literate phase of Canadian multiculturalism may prove detrimental to the long-term stability of the discourse. In general, individuals, social groups, and the media are now less knowledgeable, less concerned, less understanding, and less sensitive vis-à-vis the seminal issues involved in multiculturalism. Moreover, many users of the discourse have become unable to acknowledge and to receive the various contentions, the various practices, of other discourse users. Instead, they have struggled to fortify their own social and textual practices, again to the exclusion of others, so as to enable those practices to graduate into fully habituated and socially sanctioned multicultural literacy practices.

This article has offered a portrait of multicultural literacy in Canada over various incarnations of its development. On the whole, multicultural literacy remains a constantly shifting and amorphous structure; its codes have changed; its borders have remained porous and fluid. While government multicultural practices attempted to restrict heterogeneous renderings of the discourse, they set the stage for an explosion of at once ill-informed and self-serving contributions to multiculturalism discourse in this country. The attempt to habituate the discourse by restricting the ways in which multiculturalism discourse 
could be used, and who could use it, has opened the door to a confusing array of emergent multicultural microliteracies, while enabling the construction of new subjectivities and new redistributions of power and social roles within the larger discourse. In the end, multicultural literacy remains a hotly contested discursive space, constantly changing and variable over time, and replete with a plurality of contradictory social positions serving numerous public agendas. The discourse has become a repository for diverse biases and social ills and the media has sought to exploit those biases and social ills - a move that has effectively provoked outrage about the phenomenon and incited public controversy. As always, multicultural literacy hangs in the balance, awaiting its next codification, its next consolidation in the form of newly assembled and socially sanctioned literacy practices. 


\section{References}

Abu-laban, Yasmeen and Stasiulus, Daiva. 1992. "Ethnic pluralism under siege: Popular and partisan opposition to multiculturalism." Canadian Public Policy / Analyse de Politiques 28: 365-386.

Barton, David. 1994. Literacy: An introduction to the ecology of written language. Oxford: Blackwell.

_- Mary Hamilton and Roz Ivanic, eds. 2000. Situated literacies: Reading and writing in context. London: Routledge.

Bissoondath, Neil. 1994. Selling illusions: The cult of multiculturalism in Canada. Toronto: Penguin.

Canadian Consultative Council on Multiculturalism. 1976. Multiculturalism as state policy: Conference report. Ottawa: Author. Canadian Multiculturalism Act. 1989. Statutes of Canada (Vol. 1). Ottawa: Queen's Printer.

Department of Canadian Heritage. 2000. Annual report on the operation of the Canadian Multiculturalism Act for 1998-1999. Ottawa: Author. Frye, Northrop. 1982. Divisions on a ground: Essays on Canadian literature. Toronto: Anansi.

Gallego, Margaret A. and Sandra Hollingsworth, eds. 2000. What counts as literacy: Challenging the school standard. New York: Teachers College Press.

Gee, James Paul. 1992. The social mind: Language, ideology, and social practice (language and ideology). New York: Bergin \& Garvey.

. 1996. Social linguistics and literacies: Ideology in discourses $\left(2^{\text {nd }}\right.$ ed.). London: Falmer.

2000. "The new literacy studies: From 'socially situated' to the work of the social". In David Barton, Mary Hamilton and Roz Ivanic eds., Situated literacies: Reading and writing in context. London, Routledge: 180-196.

Goody, Jack and Ian Watt. 1968. "The consequences of literacy." In Jack Goody, ed., Literacy in traditional societies. Cambridge, Cambridge University Press: 27-84.

Goody, Jack. 1977. The domestication of the savage mind. Cambridge: Cambridge University Press.

Halliday, Michael. 1978. Language as a social semiotic. Baltimore: University of Park Press.

- 1985. An introduction to functional grammar. London: Edward Arnold Press.

Hoechsmann, Michael. 1997. "Benetton culture: Marketing difference to the new global consumer." In Stephen Harold Riggins ed., The 
language and politics of exclusion. Thousand Oaks (CA), Sage: 183202.

Hull, Glynda and Katherine Schultz, eds. 2002. School's out: Bridging out-of-school literacies with classroom practices. New York: Teachers College Press.

Hutcheon, Linda and Marion Richmond, eds. 1990. Other solitudes: Canadian multicultural fictions. Toronto: Oxford University Press.

Klein, Naomi. 2000. No logo: Taking aim at the brand bullies. Toronto: Vintage.

Légaré, Evelyn I. 1995. "Canadian multiculturalism and aboriginal people: Negotiating a place in the nation." Identities 1(4): 347 366.

Multiculturalism. May 2002. Canadian Alliance Caucus Website. Retrieved December 15, 2003, from http://www.canadianalliance.ca/ english/policy/index.asp\#_Toc8204929

Multiculturalism and Citizenship Canada. 1989. Multiculturalism: Policy and programs. Ottawa: Government of Canada.

Multiculturalism Program. 1984. Multiculturalism: Celebrating our differences. Ottawa: Government of Canada.

Padolsky, Enoch. 2000. "Multiculturalism at the millennium." Journal of Canadian Studies 35 (1): 138-160.

Patten, Steve. 1999. "The reform party's re-imagining of the Canadian nation." Journal of Canadian Studies 34 (1): 27-51.

Rich, Adrienne. 1986. Blood, bread, and poetry: Selected prose, 1979. 1985. New York: Norton.

Street, Brian. 1984. Literacy in theory and practice. Cambridge (UK): Cambridge University Press.

—_ 1993. "The new literacy studies: Guest editorial." Journal of Research in Reading 16 (2): 81-97.

-1995. Social literacies: Critical approaches to literacy in development, ethnography and education. London: Longman.

The Oxford English Dictionary (2 ${ }^{\text {nd }}$ ed.). 1989. London: Oxford University Press.

Vygotsky, Lev S. 1978. Mind in society: The development of higher psychological processes. Cambridge (Mass.): Harvard University Press. Williams, Raymond. 1985. Keywords: A vocabulary of culture and society. New York: Oxford University Press.

Wilson, Anita. 2000. "There is no escape from third-space theory: Borderland discourse and the 'in-between' literacies of prisons." In D. Barton, M. Hamilton and R. Ivanic eds., Situated literacies: Reading and writing in context. London, Routledge: 54-69. 